\title{
Implementasi Metode Certainty Factor pada Sistem Pakar Diagnosa Penyakit Ayam Berbasis Android
}

\author{
Implementation of Certainty Factor Method in Chicken Disease Diagnosis \\ Expert System based on Android
}

\author{
Muqorobin $^{1}$, Prabowo Budi Utomo ${ }^{2}$, Muhammad Nafi'uddin ${ }^{3}$, Kusrini $^{4}$ \\ ${ }_{1,2,3,4}$ Magister Teknik Informatika Universitas AMIKOM Yogyakarta \\ E-mail: *1 robbyaullah@gmail.com, ${ }^{2}$ budiutomo.prabowo@gmail.com, \\ ${ }^{3}$ napekdolanan@gmail.com, ${ }^{4}$ kusrini@amikom.ac.id
}

\begin{abstract}
Abstrak
Penelitian ini dilakukan berdasarkan kebutuhan akan adanya alat bantu bagi peternak maupun penyuluh dalam mendiagnosis penyakit pada ayam. Basis pengetahuan sepenuhnya diambil dari pengetahuan pakar yang dapat mendiagnosa dan menentukan nama penyakit yang diderita oleh ayam. Penelitian ini dibuat berdasarkan hasil analisis dengan membandingkan 4 jurnal internasional yang berjudul "Expert system of quail disease diagnosis using forward chaining method, An Expert System for Management of Poultry Diseases, Developling Mobile Expert Web-based System Using Brainstroming Method, Disease Diagnosis System". Berdasarkan keempat jurnal tersebut dapat dikembangkan inovasi baru berupa Sistem pakar diagnosa penyakit ayam menggunakan metode Certainty Factor. Metodologi penelitian menggunakan wawancara dan studi literature sehigga dapat menggumpulkan data yang lebih lengkap. Sistem Pakar ini akan di implementasikan kedalam sebuah aplikasi mobile berbasis android dengan harapan memudahkan user dalam menggunakan karena dibuat kedalam aplikasi android sehingga bisa di install dalam handphone. Hasil akhir berupa suatu informasi data penyakit dengan nilai Certainty Factor/kepastian.
\end{abstract}

Kata Kunci - Diagnosa Penyakit Ayam, Sistem Pakar, Android, Certainty Fector

\begin{abstract}
This study was conducted based on the need for tools for farmers and extension workers in diagnosingdiseases in chickens. The knowledge base is completely drawn from the expert knowledge that can diagnose and determine the name of the disease suffered by chickens. This study was based on the results of the analysis by comparing four international journals entitled "Expert system of quail disease diagnosis using forward chaining method, An Expert System for Management of Poultry Diseases, Developing Mobile Expert Web-based System Using Brainstroming Method, Disease Diagnosis System". Based on the four journals can be developed a new innovation in the form of expert system of chicken disease diagnosis using Certainty Factor method. The research methodology uses interviews and literature studies so that it can collect more complete data. Expert System will be implemented into an android-based mobile application with the hope of facilitating the user in using because it is made into the android application that can be installed in the mobile phone. The final result is an information of disease data with Certainty Factor value/certainty.
\end{abstract}

Keywords — Diagnosis of Chicken Disease, Expert System, Android, Certainty Fector 


\section{PENDAHULUAN}

Penyakit ayam merupakan masalah terbesar bagi peternak ayam, karena meningkatnya jumlah peternak ayam baik dalam pedesaan maupun dalam kota. Salah satu kendala yang dihadapi oleh peternak ayam ialah timbulnya penyakit. Banyaknya jenis penyakit ayam yang belum dikuasi oleh peternak, sehingga produktifitas ayam menjadi rendah, hal ini bisa merugikan bagi peternak ayam. dengan ditandai matinya ayam secara mendakak karena sedikitnya pengetahuan peternak ayam dalam menentukan penyakit ayam dan juga terbatasnya jumlah penyuluh ayam disetiap tempat yang sulit untuk mendatangi setiap tempat dipeternakan, maka peran seorang pakar perlu diaplikasikan kedalam sebuah program aplikasi secara mobile.

Peran teknologi informasi sangat dibutuhkan dalam membantu menanganani gejala yang diderita oleh ayam. melalui sistem kecerdasarn buatan yang di implementasikan kedalam suatu aplikasi sistem pakar diagnosa penyakit ayam. Secara umum, sistem pakar (Expert system) adalah sistem yang berusaha mengadopsi pengetahuan manusia ke komputer, agar komputer dapat menyelesaikan masalah seperti yang biasa dilakukan oleh para ahli [1]. Dengan penerapan sistem pakar maka dapat mempercepat dalam menemukan jenis penyakit yang diderita oleh ayam. Berdasarkan penelitian sebelumnya dari jurnal internasional yang berjudul Expert System of Quail Disease Diagnosis Using Forward Chaining Method, membahas tantang Sistem pakar diagnosa penyakit unggas disebabkan virus, dengan menggunakan metode Forward Chaining mampu melakukan proses diagnosa penyakit unggas dengan baik. Akan tetapi dalam proses basis pengetahuan direpresentasikan dengan menggunakan teknik IF-THEN, dimana bagian IF diikuti oleh Fakta dan bagian THEN diikuti oleh hipotesa. Namun sebagian besar peternak merasa ragu dalam penggunaan sistem tersebut, ketidakkepastian hasil yang diberikan oleh sistem membuat peternak cenderung tidak mempercayainya. Maka perlu adanya inovasi atas penelitian ini [2].

Berdasarkan pada kasus di atas, maka peneliti berusaha untuk memberikan inovasi dalam penentuan hasil dari sistem diagnose penyakit ayam yaitu dengan menggunakan metode Certainty Factor. Metode ini merupakan sebuah metode yang diusulkan oleh Shortliffe dan Buchanan pada 1975 untuk mengakomodasi ketidakpastian pemikiran (inexact reasoning) seorang pakar. Seorang pakar (contoh: dokter) sering menganalisi informasi dengan ungkapan "mungkin ", "kemungkinan besar ", "hampir pasti". Sehingga dengan adanya metode Certainty Factor ini dapat menGambarkan tingkat keyakinan seorang pakar terhadap masalah yang sedang dihadapi [1].

Di samping permasalahan ketidakpercayaan pada hasil, terdapat permasalahan lain yang dihadapi yaitu kebanyakan sistem pakar yang dibuat berbasis web, padahal banyak peternak/user belum mampu untuk menggunakan aplikasi web/komputer. Untuk permasalahan ini peneliti memberikan inovasi berupa pembuatan sistem berbasis mobile/android. Android merupakan sistem operasi mobile yang tidak membedakan antara aplikasi inti dengan aplikasi pihak ketiga. Pada Application Programming Interface (API) yang disediakan menawarkan akses ke hardware, maupun data-data ponsel sekalipun, atau data sistem sendiri [2]. Aplikasi android memiliki beberapa komponen yang penting yang semuanya telah di Uraikan kedalam sebuah Arsitektur Android. Karena Arsitektur Android berperan sebagai konsep dalam perancangan Aplikasi Android. Model Arsitektur Adroid dapat ditunjukan pada Gambar 1. 
Citec Journal, Vol. 5, No. 3, Mei 2018 - Juli 2018

\begin{tabular}{|c|c|c|c|c|}
\hline \multicolumn{5}{|c|}{ Applications and Widgets } \\
\hline Home & Contacts & Browser & Widgets & Your App Here \\
\hline \multicolumn{5}{|c|}{ Application Framework } \\
\hline $\begin{array}{c}\text { Activity } \\
\text { Manager }\end{array}$ & $\begin{array}{l}\text { Window } \\
\text { Manager }\end{array}$ & $\begin{array}{l}\text { Content } \\
\text { Providers }\end{array}$ & View System & $\begin{array}{l}\text { Notification } \\
\text { Manager }\end{array}$ \\
\hline $\begin{array}{l}\text { Package } \\
\text { Manager }\end{array}$ & $\begin{array}{l}\text { Telephony } \\
\text { Manager }\end{array}$ & Resource & $\begin{array}{l}\text { Location } \\
\text { Manager }\end{array}$ & $\begin{array}{l}\text { Sensor } \\
\text { Manager }\end{array}$ \\
\hline Libraries & & & \multicolumn{2}{|c|}{ Android Runtime } \\
\hline $\begin{array}{c}\text { Surface } \\
\text { Manager }\end{array}$ & $\begin{array}{c}\text { Media } \\
\text { Framework }\end{array}$ & SQLite & \multicolumn{2}{|c|}{ Core Libraries } \\
\hline OpenGL | ES & FreeType & WebKit & \multicolumn{2}{|c|}{$\begin{array}{l}\text { Dalvik Virtual } \\
\text { Machine }\end{array}$} \\
\hline SGL & SSL & libc & & \\
\hline \multicolumn{5}{|l|}{ Linux Kernel } \\
\hline Display Driver & $\begin{array}{l}\text { Bluetooth } \\
\text { Driver }\end{array}$ & Camera Driver & $\begin{array}{l}\text { Flash Memory } \\
\text { Driver }\end{array}$ & $\begin{array}{l}\text { Binder (IPC) } \\
\text { Driver }\end{array}$ \\
\hline Keypad Driver & USB Driver & Wifi Driver & Audio Drivers & $\begin{array}{c}\text { Power } \\
\text { Management }\end{array}$ \\
\hline
\end{tabular}

Gambar 1. Arsitektur Android

Berdasarkan Gambar 1 menunjukkan bahwa dalam android terdapat arsitektur yang terdiri dari Application dan Widgets, Application Frameworks, Libraries, Android Run Time, Linux Kernel. Melalui struktur diatas diharapkan dapat dihasilkan sistem pakar berbasis android yang mampu support pada handphone berbasis android. Hasil akhir harapan yang akan dibangun yaitu suatu sistem pakar diagnosisa penyakit ayam dengan mengimplementasikan metode certaint factor berbasis android, sehingga akan diperoleh hasil kepastian jenis penyakit yang diderita oleh ayam [3].

\section{METODE PENELITIAN}

Penelitian ini dilaksanakan dalam beberapa tahapan. Tahapan - tahapan tersebut ditujukan untuk memisahkan tingkat pencapaian proses sehingga terjadi sebuah proses yang runtut sampai dengan hasil. Proses tahapan tersebut ditunjukan pada Gambar 2.

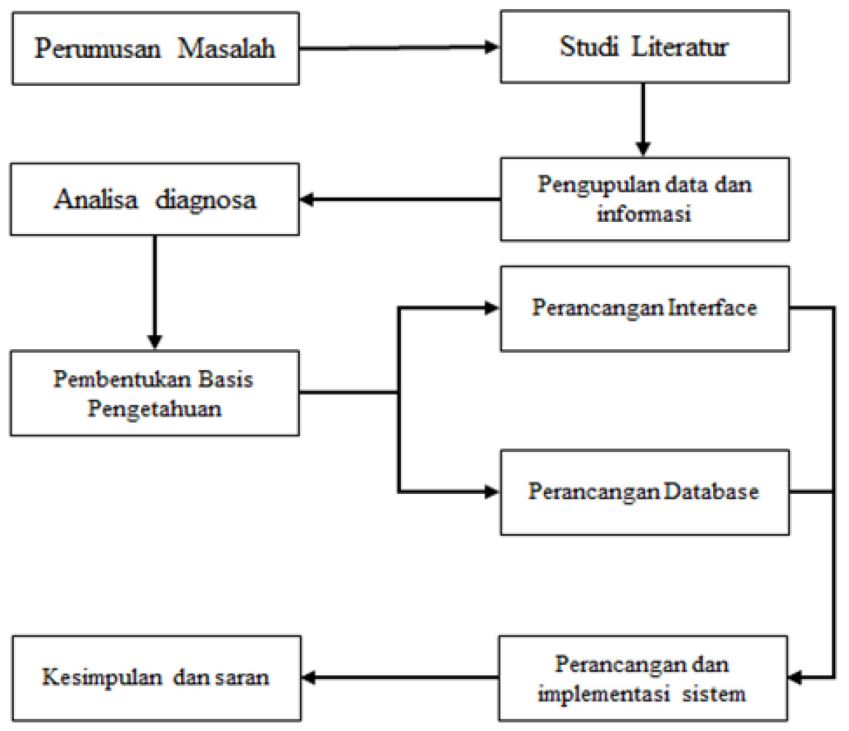

Gambar 2. Alur kinerja penelitian 
Alur kinerja penelitian yang ditunjukan pada Gambar 2 menunjukan bahwa penelitian dikerjakan dalam beberapa tahapan. Berikut ini proses tahapan dalam melakukan penelitian:

1. Perumusan masalah dalam penelitian.

2. Melakukan Studi literature dengan mengumpulkan sumber referensi yang dibutuhkan.

3. Pengumpulan data dan informasi menggunakan cara wawancara dengan pakar.

4. Analisa diagnosis dimana dilakukan pemilahan informasi dan data yang diperoleh dari sumber.

5. Proses pembentukan basis pengetahuan sekaligus akan dimasukkan nilai MB dan MD untuk setiap gejala dan penyakit.

6. Perancangan interface dan perancangan database dimana dilakukan pula pemodelan sistem yang akan dibuat.

7. Kemudian dilakukan perancangan dan impelementasi sistem.

8. Kesimpulan dan saran

\subsection{Basis Pengetahuan}

Dalam pembahasan pada penelitian ini hanya disebutkan beberapa penyakit yang diderita oleh ayam dan gejalanaya. Data ini masih bisa untuk dikembangkan lagi menjadi lebih luas apabila dikemudian hari terjadi perubahan data. Berikut ini data penyakit dan gejala ayam dapat dilihat pada Tabel 1 dan Tabel 2 sebagai berikut [4].

Tabel 1. Penyakit Ayam

\begin{tabular}{|c|c|l|}
\hline No & Kode & Nama Penyakit \\
\hline 1 & P1 & Berak Kapur \\
\hline 2 & P2 & Flu Burung \\
\hline 3 & P3 & Tipus \\
\hline 4 & P4 & Tetelo \\
\hline
\end{tabular}

Tabel 2. Gejala Ayam

\begin{tabular}{|c|c|l|}
\hline No & Kode & \multicolumn{1}{c|}{ Nama Gejala } \\
\hline 1 & G1 & Produksi telur turun \\
\hline 2 & G2 & Ayam Lesu Serta Lemah \\
\hline 3 & G3 & Nafsu Makan Berkurang \\
\hline 4 & G4 & Kelumpuhan Pada Sayap dan Kaki \\
\hline 5 & G5 & Berat telur turun dan ukuran tidak seragam \\
\hline 6 & G6 & Sulit bernafas \\
\hline 7 & G7 & Diare berwarna kehijau-hijauan \\
\hline
\end{tabular}

Berdasarkan uraian dari kedua tabel di atas maka dapat dibuat aturan-aturan relasi antara penyakit dengan gejala sehingga diperoleh basis pengetahuan pada sistem pakar sesuai Tabel 3 .

Tabel 3. Aturan Gejala Ayam

\begin{tabular}{|c|l|l|}
\hline No & \multicolumn{1}{|c|}{ Aturan Gejala } & \multicolumn{1}{|c|}{ Rule } \\
\hline 1 & $\begin{array}{l}\text { IF Ayam Lesu Serta Lemah AND Sulit bernafas THEN } \\
\text { Berak Kapur }\end{array}$ & IF G2 and G6 and then P1 \\
\hline 2 & $\begin{array}{l}\text { IF Produksi telur turun AND Nafsu Makan Berkurang } \\
\text { AND Kelumpuhan Pada Sayap dan Kaki THEN Flu } \\
\text { Burung }\end{array}$ & IF G1 and G3 and G4 then P2 \\
\hline 3 & $\begin{array}{l}\text { IF Produksi telur turun AND Sulit bernafas AND Diare } \\
\text { berwarna kehijau-hijauan THEN Tipus }\end{array}$ & IF G1 and G6 and G7 then P3 \\
\hline 4 & $\begin{array}{l}\text { IF Produksi telur turun AND Ayam Lesu Serta Lemah } \\
\text { AND Nafsu Makan Berkurang AND Kelumpuhan Pada } \\
\text { Sayap dan Kaki AND Berat telur turun dan ukuran tidak } \\
\text { seragam AND Sulit bernafas AND Diare berwarna } \\
\text { kehijau-hijauan THEN Tetelo }\end{array}$ & $\begin{array}{l}\text { IF G4 and G2 and G3 and G4 } \\
\text { and G5 and G6 and G7 then }\end{array}$ \\
\hline
\end{tabular}


Citec Journal, Vol. 5, No. 3, Mei 2018 - Juli 2018

ISSN: 2460-4259

Pengetahuan pakar berguna untuk memberikan nilai keputusan dari berbagai gejala dengan penyakit yang tepat. Karena umunya setiap penyakit terdapat beberapa gejala yang terjadi, sehingga perlu adanya pengelompokan pada basis pengetahuan di dalam program aplikasi sistem pakar.

Tabel 4. Basis Pengetahuan Sistem Pakar

\begin{tabular}{|l|l|l|l|l|l|l|}
\hline No & $\begin{array}{l}\text { Kode } \\
\text { Penyakit }\end{array}$ & $\begin{array}{l}\text { Nama } \\
\text { Penyakit }\end{array}$ & $\begin{array}{l}\text { Kode } \\
\text { Gejala }\end{array}$ & Nama Gejala & MB & MD \\
\hline 1 & P1 & Berak Kapur & G2 & Ayam Lesu Serta Lemah & 0,7 & 0,2 \\
\hline 2 & P1 & Berak Kapur & G6 & Sulit bernafas & 0,8 & 0,1 \\
\hline 3 & P2 & Flu Burung & G1 & Produksi telur turun & 0,6 & 0,2 \\
\hline 4 & P2 & Flu Burung & G3 & Nafsu Makan Berkurang & 0,7 & 0,4 \\
\hline 5 & P2 & Flu Burung & G4 & Kelumpuhan Pada Sayap dan Kaki & 0,8 & 0,1 \\
\hline 6 & P3 & Tipus & G7 & Diare berwarna kehijau-hijauan & 0,7 & 0,1 \\
\hline 7 & P3 & Tipus & G6 & Sulit bernafas & 0,6 & 0,2 \\
\hline 8 & P3 & Tipus & G1 & Produksi telur turun & 0,7 & 0,1 \\
\hline 9 & P4 & Tetelo & G1 & Produksi telur turun & 0,6 & 0,2 \\
\hline 10 & P4 & Tetelo & G2 & Ayam Lesu Serta Lemah & 0,7 & 0,2 \\
\hline 11 & P4 & Tetelo & G3 & Nafsu Makan Berkurang & 0,6 & 0,2 \\
\hline 12 & P4 & Tetelo & G4 & Kelumpuhan Pada Sayap dan Kaki & 0,6 & 0,1 \\
\hline 13 & P4 & Tetelo & G5 & $\begin{array}{l}\text { Berat telur turun dan ukuran tidak } \\
\text { seragam }\end{array}$ & 0,8 & 0,1 \\
\hline 14 & P4 & Tetelo & G6 & Sulit bernafas & 0,7 & 0,1 \\
\hline 15 & P4 & Tetelo & G7 & Diare berwarna kehijau-hijauan & 0,8 & 0,5 \\
\hline
\end{tabular}

\subsection{Metode Certaint Factor}

Certainty Factor merupakan sebuah metode yang diusulkan oleh Shortliffe dan Buchanan pada 1975 untuk mengakomodasi ketidakpastian pemikiran (inexact reasoning) seorang pakar. Seorang pakar (contoh: dokter) sering menganalisi informasi dengan ungkapan "mungkin ", "kemungkinan besar", "hampir pasti". Sehingga dengan adanya metode Certainty Factor ini dapat menggambarkan tingkat keyakinan seorang pakar terhadap masalah yang sedang dihadapi [5]. Saat ini ada dua model yang sering digunakan untuk mendapatkan tingkat keyakinan $(\mathrm{CF})$, yaitu: 1. Metode 'Net Belief' yang diusulkan oleh E.H. Shortliffe dan B. G. Buchanan. Seperti yang ditunjukkan pada persamaan [1].

$\mathrm{CF}($ Rule $)=\mathrm{MB}(\mathrm{H}, \mathrm{E})-\mathrm{MD}(\mathrm{H}, \mathrm{E})$

\section{Dimana:}

$\mathrm{CF}($ Rule) $\quad$ : Faktor kepastian

MB (H, E) : Measure of Belief (ukuran kepercayaan) terhadap hipotesis $\mathrm{H}$, jika diberikan evidence $\mathrm{E}$ (antara 0 dan 1 )

MD (H, E) : Measure of Disbelief (ukuran ketidakpercayaan) terhadap evidence $\mathrm{H}$, jika diberikan evidence $\mathrm{E}(\operatorname{antara} 0$ dan 1$)$

2. Menggunakan hasil wawancara dengan pakar. Dengan mendapatkan informasi dari hasil wawancara dengan pakar. Nilai CF (Rule) didapat dari intrepretasi "term" dari pakar, yang diubah menjadi nilai $\mathrm{CF}$ tertentu sesuai Tabel 5. Di bawah yang menjelaskan konversi nilai dari keadaan atau kondisi diubah ke dalam suatu bilangan crisp atau nilai angka yang bisa di hitung. 
Tabel 5. Nilai CF (Rule) diubah menjadi Nilai CF

\begin{tabular}{|c|l|c|}
\hline No & \multicolumn{1}{|c|}{ Kondisi } & Nilai CF \\
\hline 1 & Definitely Not (Pasti tidak) & 0.1 \\
\hline 2 & Almost Certainly Not (Hampir Pasti tidak) & 0.2 \\
\hline 3 & Probably not (kemungkinan besar tidak) & 0.3 \\
\hline 4 & Maybe not (mungkin tidak) & 0.4 \\
\hline 5 & Unknown (tidak tahu) & 0.5 \\
\hline 6 & Maybe (mungkin) & 0.6 \\
\hline 7 & Probably (kemunkinan besar) & 0.7 \\
\hline 8 & Almost Certainty (Hampir Pasti) & 0.8 \\
\hline 9 & Definitely (Pasti) & 0.9 \\
\hline 10 & Very Definitely (Sangat Pasti) & 1.0 \\
\hline
\end{tabular}

Dengan menambahkan metode Certainty Factor pada sistem pakar diharapkan user/peternak akan lebih yakin dengan hasil yang disampaikan, sebab sistem di samping menghasilkan diagnosa penyakit ayam dan memberikan nilai kepastian dari hasil tersebut.

\section{HASIL DAN PEMBAHASAN}

Pada bagian hasil dan pembahasan penelitian ini akan diuraikan kedalam konsep perancangan desain sistem yang akan membahasa proses pembuatan sistem secara umum sampai bagian implementasi dan pengujian sistem.

\subsection{Perancangan Sistem}

Dalam pembuatan sistem diperlukan penGambaran alur sistem pakar diagnosa penyakit ayam, hal ini ditujukan untuk memberikan pemahaman yang lebih baik terhadap proses sistem yang diharapkan. Alur sistem dapat di uraikan pada Gambar 3 di bawah ini [6].

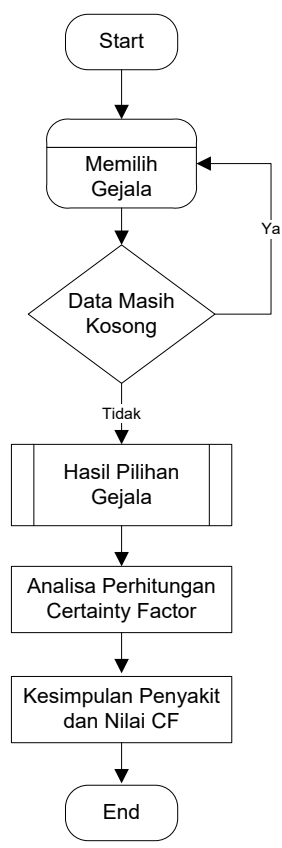

Gambar 3. Alur Sistem 
Pada Gambar 4 ditunjukkan bahwa sistem bergantung pada inputan/pilihan gejala yang diberikan oleh user. Apabila user tidak memilih maka akan dikembalikan lagi ke awal, namun apabila user memilih maka langsung dianalisa dan dihitung nilai $C F$-nya, baru kemudian diambil kesimpulan penyakit. Sedangkan desain contextnya di Gambarkan seperti pada Gambar 4 di bawah ini

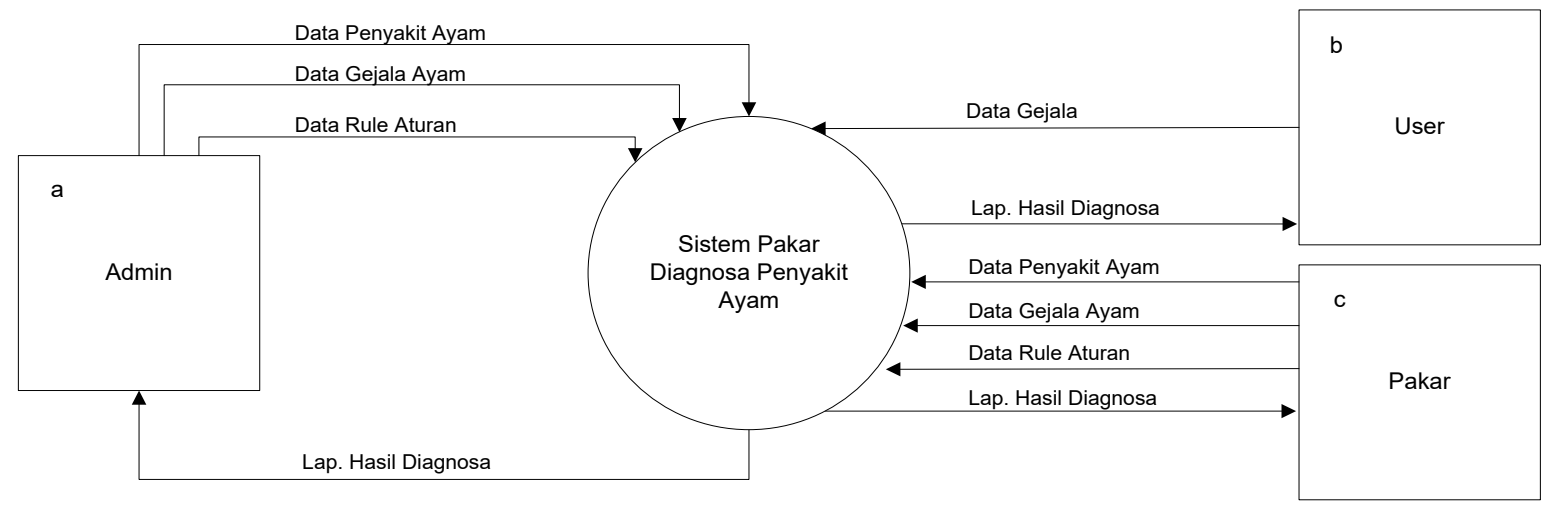

Gambar 4. Desain Context Diagram

Desain Context Diagram yang ditunjukan pada Gambar 4 dalam sistem ini terdapat tiga entitas yaitu Admin, Seorang Pakar dan User. Pada bagian Admin bertugas memberi inputan/masukan data gejala dan penyakit ayam kedalam sistem, bahkan mampu mengolah seluruh aktivitas di sistem serta dapat memperoleh hasil dari sistem [7]. Pada bagian Pakar bertugas memberikan data informasi gajala dan penyakit ayam serta rule aturan nilai pengetahuan pakar, yang akan di input kedalam sistem dan menerima hasil keluaran (diagnosa) dari sistem. Sedangkan user bertugas memberikan data masalah gejala yang diderita oleh ayamnya, data tersebut dimasukan kedalam sistem sehingga user dapat langsung melihat hasil keluaran (diagnosa) berupa nama penyakit serta analisis perbandingan tingkat kepastian penyakit dari sistem. Dari uraian diatas dapat dibuat rancangan databasenya, yang ditunjukkan dengan Gambar 5 di bawah ini [8].

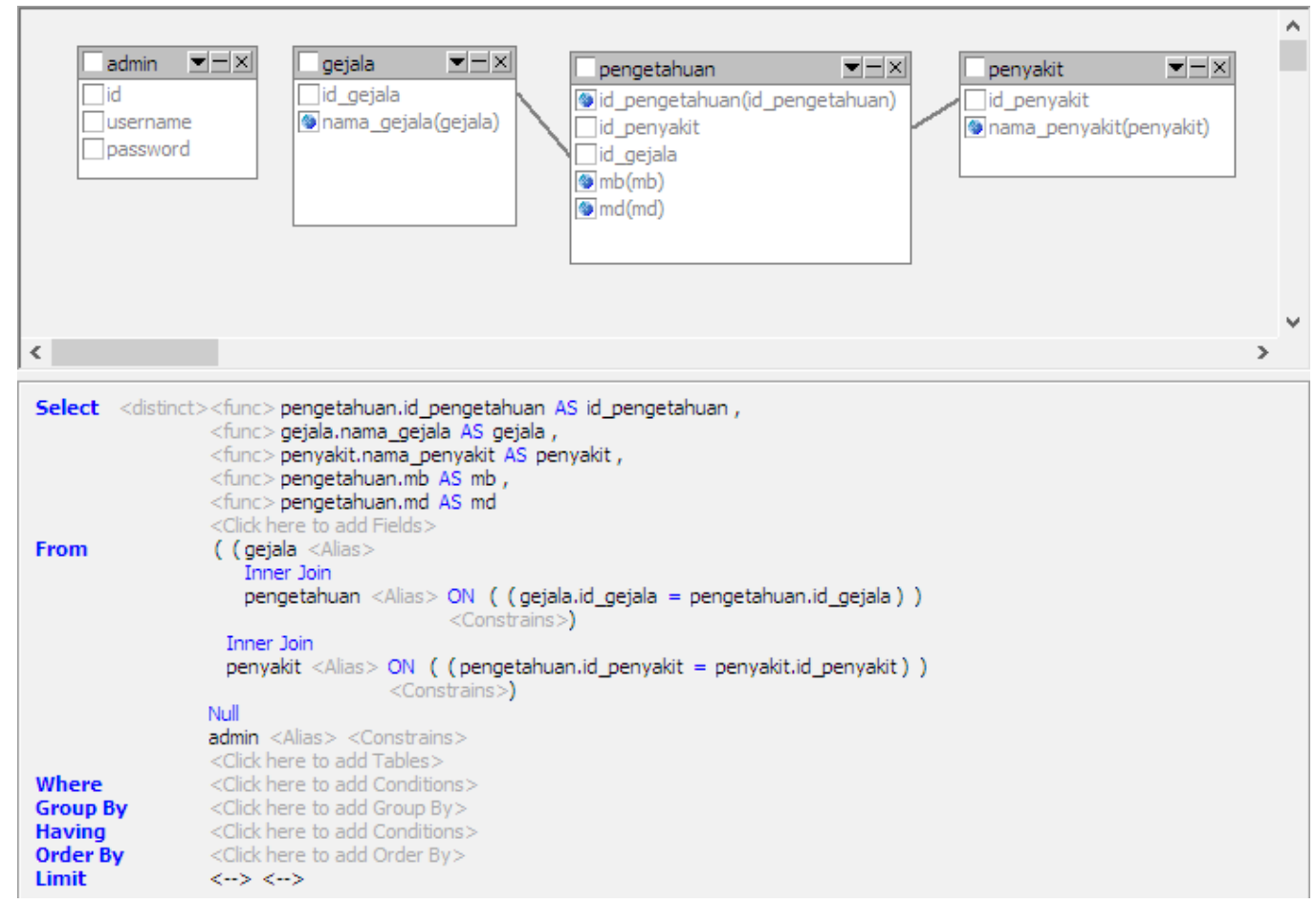

Gambar 5. Desain Relasi Database 


\subsection{Implementasi}

Sistem pakar diagnosa penyakit ayam ini diimplementasikan dalam sebuah program aplikasi android sehingga dapat mempermudah user dalam menggunakan program tersebut, karena dapat dijalankan secara offline pada mobile telephone berbasis sistem operasi android. Berikut ini hasil implementasi sistem pakar diagnosa penyakit ayam yang dibuat kedalam program aplikasi android dapat dilihat pada Gambar 6.

\begin{tabular}{|c|c|c|}
\hline $\begin{array}{l}\text { Sistem Pakar Diagnosa Penyakit Ayam } \\
\text { Certainty Factor }\end{array}$ & $\begin{array}{l}\text { Sistem Pakar Diagnosa Penyakit Ayam } \\
\text { Certainty Factor }\end{array}$ & $\begin{array}{l}\text { Sistem Pakar Diagnosa Penyakit Ayam } \\
\text { Certainty Factor }\end{array}$ \\
\hline Konsultasi & \multirow{2}{*}{$\begin{array}{l}\checkmark \text { Produksi telur turun } \\
\checkmark \text { Ayam lesu serta lemah } \\
\square \text { Nafsu makan berkurang }\end{array}$} & \begin{tabular}{|l|} 
proses 2 \\
mbbaru $=0.7$ \\
mdbaru $=0.1$ \\
\end{tabular} \\
\hline Login Admin & & $\begin{array}{l}\text { mbsementara }=\text { mblama }+(\text { mbbaru } *(1-\text { mblama }))=0.6+(0.7 \\
\text { mdsementara }=\text { mdlama }+(\text { mdbaru } *(1-\text { mdlama }))=0.2+(0.1\end{array}$ \\
\hline Exit & \multirow{2}{*}{$\begin{array}{l}\checkmark \text { Kelumpuhan pada sayap dan kaki } \\
\square \text { Berat telur turun dan ukuran tidak seragam }\end{array}$} & $\begin{array}{l}m b=\text { mbsementara }=0.87999999999999999 \\
m d=m d s e m e n t a r a=0.28 \\
c f=m b-m d=0.87999999999999999-0.28=0.599999999999\end{array}$ \\
\hline & & Proses Penyakit : P4.Tetelo \\
\hline \multirow{13}{*}{$\begin{array}{c}\text { Disusun Kelompok } 7 \\
\text {-| Muqorobin : } 17.52 .1045 \mid \text { Prabowo Budi } \\
\text { Utomo : } 17.52 .1003 \text { | Muhammad } \\
\text { Nafi'Uddin : } 17.52 .0955 \text { |- } \\
\text { Dosen Pengampu : Dr. Kusrini, M.Kom } \\
\text { ARTIFICIAL INTELLIGENCE } \\
\text { MTI-UNIVERSITAS AMIKOM YOGYAKARTA }\end{array}$} & \multirow{2}{*}{$\begin{array}{l}\checkmark \text { Sulit bernafas } \\
\square \text { Diare berwarna kehijau-hijauan }\end{array}$} & SELECT id_penyakit, mb, md, id_gejala FROM pengetahuan WHE \\
\hline & & proses 1 \\
\hline & \multirow{2}{*}{ Hitung } & $\begin{array}{l}\text { mblama }=0.6 \\
\text { mdlama }=0.2\end{array}$ \\
\hline & & proses 2 \\
\hline & SELECT id_penyakit FROM pengetahuan WHERE id_gejala IN ('G & $\begin{array}{l}\text { mbbaru }=0.7 \\
\text { mdbaru }=0.2 \\
\end{array}$ \\
\hline & Proses Penyakit: P1.Berak Kapur] & 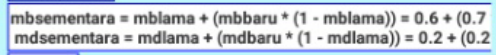 \\
\hline & proses 1 & proses 3 \\
\hline & $\begin{array}{l}\text { mblama }=0.7 \\
\text { mdlama }=0.2\end{array}$ & $\begin{array}{l}\text { mblama }=\text { mbsementara }=0.8799999999999999=0.87999995 \\
\text { mdlama }=\text { mdsementara }=0.3600000000000004=0.360000(\end{array}$ \\
\hline & \multirow{2}{*}{\begin{tabular}{l|} 
proses 2 \\
mbbaru $=0.8$ \\
mdbaru $=0.1$ \\
\end{tabular}} & $\begin{array}{l}\text { mbbaru }=0.6 \\
\text { mdbaru }=0.1 \\
\end{array}$ \\
\hline & & $\begin{array}{l}\text { mbsementara }=\text { mblama } *(\text { mbbaru } *(1-\text { mblama }))=0.879999 ! \\
\text { mdsementara }=\text { mdlama } *(\text { mdbaru * }(1-\text { mdlama }))=0.360000\end{array}$ \\
\hline & $\begin{array}{l}\text { mbsementara }=\text { mblama }+(\text { mbbaru * }(1-\text { mblama }))=0.7+(0.8 \\
\text { mdsementara }=\text { mdlama }+(\text { mdbaru * }(1-\text { mdlama }))=0.2+(0.1\end{array}$ & $\begin{array}{l}\mathrm{mb}=\text { mbsementara }=0.952 \\
\mathrm{md}=\text { mdsementara }=0.42400000000000004\end{array}$ \\
\hline & \multirow{2}{*}{$\begin{array}{l}m b=\text { mbsementara }=0.94 \\
m d=m d s e m e n t a r a=0.28 \\
\mathrm{cf}=\mathrm{mb}-\mathrm{md}=0.94-0.28=0.65999999999999999\end{array}$} & $\mathrm{cf}=\mathrm{mb}-\mathrm{md}=0.952-0.42400000000000004=0.527999999$ \\
\hline & & Penyakit Terbesar = P1.Berak Kapur dengan Nilai CF 0.659999؟ \\
\hline
\end{tabular}

Gambar 6. Hasil Implementasi Aplikasi Android

\subsection{Pengujian Sistem}

Berdasarkan hasil implementasi sistem dengan memberikan contoh daftar gejala penyakit, diperoleh hasil penyakit berupa Berak Kapur karena memiliki nilai $\mathrm{CF}$ tertinggi $=$ 0.65999 atau 0.66. Dari hasil perhitungan aplikasi android di atas maka sistem akan diuji dengan menggunakan metode certaint factor dengan memberikan contoh studi kasus yang sama sesuai dengan gejala yang telah diterapkan [9].

Contoh kasus:

Seorang peternak ayam ingin tau penyakit apa yang diderita oleh ayamnya, dengan gejala yang diderita ayam seperti produksi telur turun, ayam lesu serta lemah, kelumpuhan pada sayap dan kaki dan sulit bernafas. factor [10]:

Berkut ini langkah-langkah dalam melakukan perhitungan pada metode certainty

1. Menyederhanakan masalah

Berdasarkan contoh kasus di atas, user telah memilih beberapa gejala yang diderita oleh ayam sehingga dapat disusun dalam sebuah Tabel 6 berikut. 
Citec Journal, Vol. 5, No. 3, Mei 2018 - Juli 2018

Tabel 6. Penyederhanaan Gejala Terpilih

\begin{tabular}{|c|c|l|l|}
\hline No & Kode Gejala & Nama Gejala & Kode Penyakit \\
\hline 1 & G1 & Produksi telur turun & P2, P3, P4 \\
\hline 2 & G2 & Ayam Lesu Serta Lemah & P1, P4 \\
\hline 3 & G4 & Kelumpuhan Pada Sayap dan Kaki & P2, P4 \\
\hline 4 & G6 & Sulit bernafas & P1, P3, P4 \\
\hline
\end{tabular}

2. Klasifikasi gejala sesuai penyakitnya

Melakukan proses klasisfikasi gejala sesuai dengan penyakit yang diderita oleh ayam dapat dilihat pada Tabel 7.

Tabel 7. Klasifikasi Penyakit Terpilih

\begin{tabular}{|c|c|l|l|}
\hline No & $\begin{array}{c}\text { Kode } \\
\text { Penyakit }\end{array}$ & \multicolumn{1}{|c|}{$\begin{array}{c}\text { Nama } \\
\text { Penyakit }\end{array}$} & \multicolumn{1}{c|}{ Kode dan Gejala } \\
\hline 1 & P1 & Berak Kapur & $\begin{array}{l}\text { (G2 = Ayam Lesu Serta Lemah), G6 = Sulit } \\
\text { bernafas })\end{array}$ \\
\hline 2 & P2 & Flu Burung & $\begin{array}{l}\text { (G1 = Produksi telur turun), (G4 = Kelumpuhan } \\
\text { Pada Sayap dan kaki) }\end{array}$ \\
\hline 3 & P3 & Tipus & $\begin{array}{l}\text { (G6 = Sulit bernafas), (G1 = Produksi telur } \\
\text { turun })\end{array}$ \\
\hline 4 & P4 & Tetelo & $\begin{array}{l}\text { (G1 = Produksi telur turun), (G2 = Ayam Lesu } \\
\text { serta lemah), (G4 = Kelumpuhan pada sayap } \\
\text { dan kaki), (G6 = Sulit bernafas) }\end{array}$ \\
\hline
\end{tabular}

3. Menyiapkan Basis Pengetahuan

Basis pengetahuan diambil dari pengetahuan pakar yang dapat dilihat penjelasan dari Tabel 4 , sehingga berdasarkan tabel tersebut maka cukup diambil penyakit sesuai dengan gajala yang telah dipilih oleh user, untuk kemudian disusun sebagaimana ditunjukan Tabel 8 .

Tabel 8. Basis Pengetahuan Penyakit Terpilih

\begin{tabular}{|c|c|l|c|l|c|c|}
\hline No & $\begin{array}{c}\text { Kode } \\
\text { Penyakit }\end{array}$ & $\begin{array}{c}\text { Nama } \\
\text { Penyakit }\end{array}$ & $\begin{array}{c}\text { Kode } \\
\text { Gejala }\end{array}$ & \multicolumn{1}{|c|}{ Nama Gejala } & MB & MD \\
\hline 1 & P1 & Berak Kapur & G2 & Ayam Lesu Serta Lemah & 0,7 & 0,2 \\
\hline 2 & P1 & Berak Kapur & G6 & Sulit bernafas & 0,8 & 0,1 \\
\hline 3 & P2 & Flu Burung & G1 & Produksi telur turun & 0,6 & 0,2 \\
\hline 4 & P2 & Flu Burung & G4 & $\begin{array}{l}\text { Kelumpuhan Pada Sayap dan } \\
\text { Kaki }\end{array}$ & 0,8 & 0,1 \\
\hline 5 & P3 & Tipus & G6 & Sulit bernafas & 0,6 & 0,2 \\
\hline 6 & P3 & Tipus & G1 & Produksi telur turun & 0,7 & 0,1 \\
\hline 7 & P4 & Tetelo & G1 & Produksi telur turun & 0,6 & 0,2 \\
\hline 8 & P4 & Tetelo & G2 & Ayam Lesu Serta Lemah & 0,7 & 0,2 \\
\hline 9 & P4 & Tetelo & G4 & $\begin{array}{l}\text { Kelumpuhan Pada Sayap dan } \\
\text { Kaki }\end{array}$ & 0,6 & 0,1 \\
\hline 10 & P4 & Tetelo & G6 & Sulit bernafas & 0,7 & 0,1 \\
\hline
\end{tabular}


4. Perhitungan

Proses perhitungan pada Metode Certainty Factor ditunjukan pada Tabel 9 dan Hasil

Perhitungan serta perangkingan penyakit ditunjukan pada Tabel 10.

Tabel 9. Proses Perhitungan Certainty Factor

\begin{tabular}{|c|c|c|c|c|c|c|c|c|}
\hline No & Penyakit & Gejala & $\begin{array}{c}\text { MB } \\
\text { Lama }\end{array}$ & $\begin{array}{c}\text { MD } \\
\text { Lama }\end{array}$ & $\begin{array}{c}\text { MB } \\
\text { Baru }\end{array}$ & $\begin{array}{l}\text { MD } \\
\text { Baru }\end{array}$ & $\begin{array}{c}\text { Nilai } \\
\text { CF }\end{array}$ & Keterangan \\
\hline \multirow{2}{*}{1} & P1 & G1 & 0 & 0 & 0,7 & 0,2 & \multirow{2}{*}{0,66} & \multirow{2}{*}{ Berak Kapur } \\
\hline & P1 & $\mathrm{G} 2$ & 0,7 & 0,2 & 0,8 & 0,1 & & \\
\hline \multirow{2}{*}{2} & $\mathrm{P} 2$ & G1 & 0 & 0 & 0,6 & 0,2 & \multirow{2}{*}{0,64} & \multirow{2}{*}{ Flu Burung } \\
\hline & $\mathrm{P} 2$ & G2 & 0,6 & 0,2 & 0,8 & 0,1 & & \\
\hline \multirow{2}{*}{3} & $\mathrm{P} 3$ & G1 & 0 & 0 & 0,6 & 0,2 & \multirow{2}{*}{0,60} & \multirow{2}{*}{ Tipus } \\
\hline & $\mathrm{P} 3$ & G2 & 0,6 & 0,2 & 0,7 & 0,1 & & \\
\hline \multirow{2}{*}{4} & $\mathrm{P} 4$ & G1 & 0 & 0 & 0,6 & 0,2 & \multirow{2}{*}{0,52} & \multirow{2}{*}{ Tetelo } \\
\hline & $\mathrm{P} 4$ & G2 & 0,6 & 0,2 & 0,7 & 0,2 & & \\
\hline \multirow{2}{*}{5} & P4 & G3 & 0,88 & 0,36 & 0,6 & 0,1 & \multirow{2}{*}{0,50} & \multirow{2}{*}{ Tetelo } \\
\hline & $\mathrm{P} 4$ & G4 & 0,95 & 0,24 & 0,7 & 0,1 & & \\
\hline
\end{tabular}

Tabel 10. Hasil Perhitungan Certainty Factor

\begin{tabular}{|c|l|c|c|}
\hline $\begin{array}{c}\text { Kode } \\
\text { Penyakit }\end{array}$ & $\begin{array}{c}\text { Hasil } \\
\text { Perhitungan }\end{array}$ & $\begin{array}{c}\text { Hasil CF } \\
\text { (Certainty Factor) }\end{array}$ & Rank \\
\hline P1 & Berak Kapur & 0,66 & 1 \\
\hline P2 & Flu Burung & 0,64 & 2 \\
\hline P3 & Tipus & 0,60 & 3 \\
\hline P4 & Tetelo & 0,50 & 4 \\
\hline
\end{tabular}

Berdasarkan hasil perhitungan dignosa penyakit ayam dengan metode certaint factor diatas maka dapat diambil kesimpulan bawah ayam mendertai penyakit Berak Kapur karena memili nilai CF tertinggi yaitu $\mathbf{0 , 6 6}$. Berdasarkan hasil perhitungan pada aplikasi dan hasil perhitungan pada manual dengan metode certaint factor maka pengujian sistem dinyatakan valid, sehingga sistem layak untuk di impelmentasikan dalam dunia kerja.

\section{KESIMPULAN}

Berdasarkan hasil analisa dalam Impelementasi Metode Certainty Factor pada Diagnosa Penyakit ayam maka dapat disimpulkan sebagai berikut:

1. Implementasi Metode Certainty Factor telah mampu melakukan proses diagnosa penyakit ayam yang cukup dipercayai oleh user dengan didukung oleh nilai kepercayaan/CF yang dihasilkan yaitu 0,66 berdasarkan hasil pengujian sistem yang telah dilakukan.

2. Sistem Diagnosa penyakit ayam dengan metode Certainty Factor yang di implementasikan pada Aplikasi Android telah berjalan dengan biak, berdasarkan hasil perbandingan uji manual dengan hasil perhitugan pada Aplikasi diperoleh hasil nilai yang sama, sehingga sistem dinyatakan valid.

\section{SARAN}

Dalam penelitian ini masih terdapat kelemahan dan kekurangan, sehingga dimasa yang akan datang dapat dikembangkan lagi, karena itu disarankan.

1. Pada penelitian selanjutnya bisa dikembangkan lagi untuk penambahan update database penyakit secara online, sehingga data penyakit dan gejala dapat berisi secara aktual. 
2. Pada penelitian selanjutnya bisa dikembangkan lagi pada basis pengetahuan pakar, jika terjadi perubahan maka perlu adanya keilmuan dari pakar terhadap gajala dan penyakit yang didertia oleh ayam.

3. Pada pengujian sistem, perlu adanya penambahan metode. Sehingga tidak hanya terpaku pada pengujian perbandingan antara pakar dan sistem.

\section{DAFTAR PUSTAKA}

[1] Kusrini, 2009, Aplikasi Sistem Pakar, Andi Offset, Yogyakarta

[2] Wibisono, 2011, Mobile Programming dengan Android, Andi Offset, Yogyakarta

[3] Ramadhan, M., 2011, Sistem Pakar dalam Mengidentifikasi Penyakit Kanker pada Anak Sejak Dini dan Cara Penanggulanganya, Jurnal SAINTIKOM, No. 2, Vol. 10, Hal. 125-135

[4] Herlambang, R., Bayu, K., 2014, Jadi Jutawan dari Beternak Sapi Potong dan Sapi Perah, FlashBooks, Yogyakarta

[5] Yanto, R., 2017, Penerapan Metode Analytical Hierarchy Process dalam Upaya Peningkatan Kualitas Objek Wisata, Citec Journal, No. 3, Vol. 4, Hal. 163-173

[6] Kusumadewi, 2009, Artivicial Intelligence (Teknik dan Aplikasi), Graha Ilmu, Yogyakarta.

[7] Nugroho, B., 2014, Aplikasi Sistem Pakar dengan PHP Dan EditorDreamweaver, Gava Media, Yogyakarta.

[8] Norhikmah., Kusrini., Arief, M. R., 2014, Perancangan Sistem Pendukung Keputusan dalam Memilih Sekolah Tinggi Ilmu Kesehatan di Yogyakarta, Citec Journal, No. 2, Vol. 1, Hal. $154-170$

[9] Marlina., Ikbal., 2016, Implementasi Metode Certainty Factor pada Unggas, Jurnal TIKA, No. 2, Vol. 1, hal 48-63.

[10] Turban, E., Aronson, J. E., Liang, T., 2009, Decision Support Systems and Intelligent Systems, Andi Offset, Yogyakarta. 